\section{GRAPHIC DESIGN IN THE ASPECT OF COMBINING UNCONNECTED}

\author{
Inna Cherkesova, \\ https://orcid.org/0000-0003-3274-2220 \\ Professor, Honored Artist \\ of Ukraine, \\ Odessa National \\ Maritime University, \\ Odesa, Ukraine \\ in_dizain@ukr.net
}

\section{ГРАФІЧНИЙ ДИЗАЙН В АСПЕКТІ ПОЄДНАННЯ НЕПОЄДНУВАНОГО}

\author{
Інна Черкесова, \\ профресор, заслужений діяч \\ мистецтв України, \\ Одеський національний \\ морський університет, \\ Одеса, Україна \\ in_dizain@ukr.net
} https://orcid.org/0000-0003-3274-2220

\begin{abstract}
The purpose of our research is to consider graphic design in the aspect of combining the incompatible - complementarity, and to identify ways to organize and develop the professional thinking of a designer. Research methods analysis of synthesis of scientific, technical and humanitarian cultures in the field of graphic design; an attempt to apply the methods of researching the science of "centauristics» to the study of contemporary design. Scientific novelty. For the first time an attempt is made to apply the «centauristic» method to the study of the state of modern graphic design. Conclusions. Graphic forms of information cause certain feelings and create a positive or negative (in the case of unsuccessful forms) environment, adjust the emotional state of people to callogathy or the degradation of behavioral models. The principle of complementarity should be embedded in the modern education base, especially in the professional education of the design industry. This will help to shape not only a harmoniously developed personality, but also to become a specialist in design, capable of design thinking, generation of ideas and their implementation in the reality.
\end{abstract}

Keywords: graphic design, centauristics, project activity, complimentarity.

\section{Анотація}

Мета дослідження полягає у розгляді графічного дизайну в аспекті поєднання непоєднуваного - компліментарності, та у виявленні шляхів організації та розвитку професійного мислення дизайнера. Методи дослідження - аналіз синтезу науково-технічної і гуманітарної культур у сфері графічного дизайну; спроба застосування методів дослідження «кентавристики» до дослідження сучасного дизайну. Наукова новизна. Вперше здійснюється спроба застосування «кентавристичного» методу до дослідження стану сучасного графічного дизайну Висновки. Графічні форми інформації викликають певні відчуття істворюють позитивне або негативне (за умов невдалих форм) середовище, налаштовують емоційний стан людей на калокагатію або на деградацію поведінкових моделей. Принцип компліментарності (доповнюваності) потрібно закласти у базу сучасної освіти, особливо у фахову освіту галузі дизайну. Це сприятиме формуванню не тільки гармонійно розвинутої особистості, а й становленню фахівця дизайну, спроможного до проектно-творчого мислення, генерації ідей та їхнього втілення у реальність.

\section{Ключові слова:}

графічний дизайн, кентавристика, проектна діяльність, компліментарність. 
Вступ 1 Суспільство сьогодні знаходиться на етапі тотальної інформатизації. Стало вже тривіальним нагадування: інформація найбільша цінність, хто володіє інформацією - володіє світом тощо. Інформація є дієвим засобом комунікації на всіх рівнях суспільного життя, як в окремому регіоні, так і в планетарному масштабі. Інформація існує у таких формах: вербальних (аудіальних, друкованих), візуальних (у реальності та у віртуалі: графіка, фото, кіно, об'ємні матеріальні форми), кінестетичних (відчуття та враження). Графічний дизайн є засобом та інструментом створення (оформлення) інформації для ії сприйняття, осмислення, споживання людським загалом. За голландським всесвітньо визнаним теоретиком іпрактиком Гертом Думбаром, графічний дизайн визначається як соціальноінформаційна система спілкування, тобто система плідних зв'язків (Мискарян, 2007).

Англомовне поняття «дизайн» включає в себе аспект проектної діяльності, адже кожний дизайнерський задум - це ідея проекту для реалізації у реальності (середовищі людського буття) або у віртуальній реальності. Вдалою ілюстрацією до цього твердження можна розглядати такий факт, що у фразі з англомовної Біблії часів Реформації (16 ст., Мартін Лютер), - «Спочатку Бог створив небо та землю», - використовується слово «designed». То виходить, що Світ був «спроектований» Творцем (Дзогій, 2013). Ця інформація дозволяє зрозуміти основи наукових тверджень про поєднання непоєднуваного Даниїла Даніна, в аспекті яких ми спробуємо розглянути графічний дизайн у сьогоднішньому стані інформаційного суспільства. Розуміння фахівцями-викладачами та виконавцями шляхів розвитку графічного дизайну дозволяє вчасно реагувати на швидкі зміни потоків інформації.

\section{Мета дослідження}

Рівень освоєння розвитку новітніх технологій визначає професійний компетентнісний рівень фахівців галузі дизайну взагалі і графічного дизайну зокрема, що вимагає визначення пріоритетів у дизайнерській освіті усіх рівнів. У різних інформаційних джерелах Інтернету постійно зазначається про важливість навчити молоде покоління мислити. У галузі дизайну поєднуються раціональний та образно-творчий види мислення. Синтетичність дизайну утворюється саме поєднанням науково-технічного і гуманітарного, раціонально-логічного й образно-чуттєвого, емоційного способів сприйняття та створення форми. Графічний дизайн у реальному та віртуальному просторах стає засобом формалізації інформації з метою якнайкращого їі сприйняття споживачем/користувачем. Графічний дизайн створює форми інформаційної навігації в усіх видах реальності, що допомагає людям робити свій вибір у власному бутті. Тра- 
диційні напрямки графічного дизайну (усі види поліграфії) поєдналися з візуалізацією за допомогою цифрових технологій, що вимагає набуття компетенцій як у галузі мистецтва, так і в галузі науково-технічної - комп'ютерної графіки. Так відбувся процес поєднання непоєднуваного - мистецтва з інженерією.

Мета нашого дослідження полягає в аналізі такого синтезу науково-технічної і гуманітарної культур у сфері графічного дизайну та виявлення шляхів організації та розвитку професійного мислення.

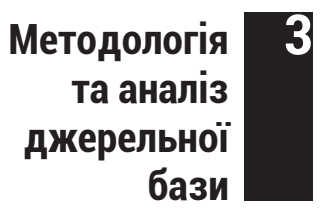

Завдяки різним параметрам і характеристикам інформації людина пізнає світ. Ще у 70-х рр. XX ст. визнаний культуролог Брюс Арчер разом з колегами відділу інновацій Лондонського Королівського коледжу мистецтв визначив дизайн як «третю культуру»: перша культура - науково-технічна, друга - гуманітарна, а третя - дизайн як засіб нового, широкого, проблемного, творчого мислення. Метою такого стає переосмислення всього, що створено людством, та на підставі особливих підходів проектування нового, що оптимально відповідає потребам людини та людства (Вершинин, 2018). Було надано вичерпне, на нашу думку, глибоке визначення: «Дизайн - це сукупний досвід матеріальної культури і сукупний масив знання, навичок та цінностей, що втілено у мистецтві планування, винахідництва формоутворення, виконання» (Вершинин, 2018).

Брюс Арчер визначив предмет, метод, цінності третьої культури, - дизайну, - відносно до двох перших. Предметом дослідження дизайну є світ, створений людиною. Методом дослідження моделювання, створення образів, синтезування. Цінностями дослідження - практичність, винахідливість, зацікавленість у відповідності призначенню (Вершинин, 2018, с. 9-10).

Американський методолог дизайну К. Александер зазначив, що суттю дизайнерської діяльності є конструювання моделі. На його думку дизайнер вчиться думати в ескізних формах: перетворює абстрактну модель вимог споживача у конкретний образ предмета (Вершинин, 2018, с. 11-12).

Все ж метою дизайнерського методу визнається потреба в характеристиках матеріальної форми та їі естетичних властивостях, а не створення художнього образу, що є метою мистецтва. Дизайн формується на межі техніки (технологій) і мистецтва і стає самодостатньою, самостійною сферою діяльності людини. Американський теоретик дизайну К. Джонс визначив відмінність: якщо наука є аналітичною і досліджує форми, що вже існують, то дизайн є конструктивним і започатковує нові форми, а дизайнерська діяльність є процесом синтезу моделей, а не процесом їхнього осмислення (Вершинин, 2018, с. 11-12). 
Сферою створення та тиражування інформації у суспільстві до середини XX ст. була поліграфічна галузь. Тексти оформлювалися різними стилями шрифтів з карбами (серіфами) й гротескними шрифтами (без серіфів). Зростання кількості інформації мотивувало до створення й впровадження у поліграфічне виробництво все нових інових шрифтів - варіантів антикви й гротеску.

В середині XX ст. відбулася епохальна подія: Айвен Сазерлед, тоді ще молодий аспірант Інституту технологій Карнегі, почав розробляти програму «Sketchpad», що дозволила на екрані монітора отримувати графічні форми й обробляти їх (масштабувати, обрізати, витягувати або стискати тощо). Саме ці інноваційні винаходи стали основою сучасного графічного дизайну. Але компетентності володіння комп'ютерними програмними інструментами з комп'ютерних фахівців не створили художників і дизайнерів. Потрібна досить ґрунтовна основа художньої освіти: знання законів утворення композиції, основи колористики, володіння технікою рисунка. Лінія є головним засобом вираження ідей у графічних формах на площині (папір, полотно, стіна тощо). Лінія утворюється в реальності рухами руки з інструментом: олівець, перо, різець, пензель тощо. Лінія на екрані монітора є відображенням математичних формул для кожної своєї точки. Сазерленд винайшов спосіб утворення лінії між двома заданими точками на екрані монітора за допомогою електронного олівця.

Комп'ютерні графічні технології сьогодні дозволяють створювати імітації форм від двовимірних до об'ємних - 3D та симуляції їх взаємодії в русі у віртуальному просторі. Візуалізація стала змістом графічного дизайну. Форми типографії завдяки комп'ютерним технологіям стали факторами організації середовища та впливу на соціальні форми буття людини в інформаційному суспільстві. Графічні форми, - шрифти рекламних написів, назв різноманітних установ, піктограми навігації, друкована продукція від постерів до книг, - все це є предметом дизайну середовища, його інформаційної складової. Потрібно зазначити вже визнане: наше середовище, засмічене продуктами невдалого графічного дизайну, наносить шкоду почуттям міри і краси, закладених у людині від народження. Людина, яка з дитинства виховується у середовищі потворного (візуальні форми, звуки, запахи), дорослою не спроможна до повноцінної творчої діяльності, а налаштована на руйнівні дії у суспільстві й самій собі. Графічний дизайн формами літер, емблем, логотипів, написів створює інформаційне середовище буття, що повинно задовольняти потреби людини іє вагомою складовою дизайну середовища. 
Дизайн середовища - це втілення ідей у матеріальні й віртуальні функціональні форми з метою якісного задоволення біогенних, матеріальних і духовних потреб людини у планетарних умовах іiі життєдіяльності (Черкесова, 2012). На відповідальності дизайнера за якість продукту своєї творчості наполягали світові теоретики і практики, педагоги у галузі дизайну, такі як Вальтер Гропіус, Анрі Ван де Вельде, Віктор Папанєк, Томас Мальдонадо, Карл Кантор, Євген Розенблюм та інші. Безпека дизайн-продукту людського середовища зрозуміла і не вимагає доведення. Це вже аксіома. Освіта в галузі дизайну повинна спиратися на цю аксіому: безпека середовища, що творить людина на планеті Земля.

Дизайн як професія утворювалася паралельно у вищих навчальних закладах з протилежним культурологічним фундаментом Західної та Східної Європи: Баугауз (Німеччина), Київський художній інститут (Україна) та ВХУТЕМАС (пізніше ВХУТЕІН, Радянська Росія) у 20-х рр. XX ст. У Німеччині протестантська етика за основу середовища буття має простоту, чистоту, побутову скромність, ревну працю, надійність, якість. Покоління, що ментально сформувалися на протестантській етиці раціоналізму й досягнень англосаксонського світу, зробили якість німецького матеріального продукту загальновизнаною у світі. Німецьке - означає якісне. Слов'янський культурний тип формується на емоціях, християнській чуттєвості. Він характеризується художньо-образним мисленням, що яскраво розкрито у неповторній та різноманітній спадщині декоративноужиткового мистецтва.

Феномен зародження дизайну у двох типах культур відбувся одночасно - це незаперечний історичний факт. Шляхи розвитку виявилися різними саме на підставі типів мислення: раціонального та емоційного, що зумовило й певні результати дизайнерської діяльності. Країни Західної Європи не просто створюють нові технології, а швидко використовують їх з метою отримати новий продукт і користуватися ним на благо людей. Кінестетична емоційність людей (мешканців, споживачів/користувачів) Східної Європи є платформою породження абстрактних ідей, котрі не втілюються у реальність. Тому нові технології, умови користування ними - все це приходить до нас із Заходу.

Стосовно графічного дизайну взагалі й зокрема шрифтового дизайну ми користуємося розробками латиниці (пресловутий Times New Roman). Корпорація Monotype Imaging (правовласник ряду шрифтів) продає нам ліцензії на певний термін користування шрифтовими гарнітурами. Української абетки як загально визнаної у світі не існує. Попри наполегливу працю Василя Чебаника, історичних розробок українського шрифту 
від Нарбута до Хоменка, українська абетка не визнана Корпорацією цифрового шрифтового продукту. Виростають нові покоління в Україні, котрі вже краще сприймають інформацію латинкою, ніж кирилицею, швидше натискають на кнопки клавіатур, ніж каліграфічно пишуть пером, захоплюються фантазійними пригодами Гаррі Потера, героїв Нарнії тощо. Вони вже не будуть читати українських класиків, котрі представлені у варіаціях шрифту петровської «гражданки», що є насправді формами латинки.

Зрозуміло, що тільки на патріотичному ентузіазмі, на любові до української культури шрифтарі, зокрема Василь Чебаник, віддали багато часу свого творчого життя на створення української абетки. Але без потужної підтримки відповідних державних структур українська абетка, знаменитий вже шрифт «Рутенія», не стануть формами інформації, зрозумілої у споживацькому суспільстві. Потрібно погодитися з ситуацією засміченого середовища потворними формами латиниці у перекладі на форми кирилиці. Саме зміна на українські шрифтові форми у середовищі життя народу України буде сприяти змінам у сприйнятті інформації на ментальному рівні.

\section{Результати дослідження}

Раціональна політика змін шрифтових форм, послідовність впровадження у суспільстві саме українських шрифтів буде стимулювати розвиток інаціонального графічного дизайну, і методів вищої освіти дизайну середовища, складовою якого $є$ графічний дизайн. Перевага емоційних складових мислення над раціональними приводить до того, що галуззю дизайну починають керувати люди, що не є фахівцями у цій галузі. А це, зі свого боку, веде до вихолощення сенсу дизайн-освіти, до розмноження ремісників комп'ютерних графічних технологій, котрі вже не спроможні стати генераторами інноваційних ідей. Такі ремісники від технологій використовують у своїх розробках вже створені видатними дизайнерами форми, шаблони, порушуючи закони етики та авторського права. Крім того, впливовим фактором є й закони ринку, невблаганні йжорсткі. Наші талановиті молоді фахівці, що обмежені у вільному творчому мисленні ринковими відносинами, нерідко утримуються на виконавсько-ремісничому рівні, що, звісно, не сприяє розвитку ні окремої особистості, ні дизайнерської галузі взагалі.

На сьогодні вже можна констатувати за історичними фактами, що дизайнерська освіта та діяльність випускників західно-європейської культури виявилися максимально продуктивними у створенні середовища людського буття інформаційного суспільства. Розумне поєднання раціонального з естетичними характеристиками у створенні форми, - реальної або вірту- 
альної, - дозволяють формувати середовище життя людини з максимальним задоволенням її потреб.

Дизайн як професійний напрям творчо-проектної діяльності намагається синтезувати професійні компетенції інженерно-технічного рівня (фахівця IT, комп'ютерної графіки), художника, архітектора, психолога, менеджера, маркетолога. На певних етапах розробки проекту дизайнер виконує функції перелічених фахових напрямків. Утворюється своєрідна форма проектного творення, яку можна позначити як «кентавр» - поєднання непоєднуваного. Дизайн взагалі $є$ «кентавром»: поєднанням науки, техніки і мистецтва. Таке поєднання різних типів мислення привело до виникнення й розвитку самостійного напрямку проектно-творчої діяльності, що має власну історію, теорію, практику (Дзогій, 2013). Даниїл Данін, творець суперечливої і майже невизнаної теорії «кентавристики», передбачив появу уреальності феноменів поєднання непоєднуваного, наукового і художнього, що полягає в тому, що поєднується художньо-образне мислення з логічним, науковим (Горянин, 2018). Такі різні види мислення, осягнення дійсності, роздумів про світоустрій, - втілення науковості й художності (естетики) в одній особистості, - формують людей-фахівців подвійної обдарованості, що досягають успіху в обох сферах - науки і мистецтва одночасно, наприклад, Леонардо да Вінчі, Олександр Бородін, Анрі Ван де Вельде, Василь Кричевський

Д. Данін (Данин, 1997) висуває гіпотезу про можливе утворення нової науки, предметом якої буде структура парадоксів, оксюморонів іантитез в аспекті поєднання непоєднуваного. При цьому він наголошує на принциповій відмінності цього поєднанні від закону боротьби й єдності протилежностей, адже боротьби як такої в цій гіпотезі не існує. Д. Данін використовує символ кентавра, який утворено в порозумінні двох істот вершник не гонить коня, а кінь не намагається його скинути. Кентавр - це, на думку вченого, метафора компромісу, конвергенції та компліментарності. Потрібно зазначити, що Д. Данін розглядав свою «кентавристику» як спробу наукового опанування універсального феномену поєднання непоєднуваного у природі, історії, культурі.

Дизайн взагалі і є данінський «кентавр», що завдяки поєднанню зусиль обдарованих особистостей інженерів, виробників, митців протягом півтори сотні років свого розвитку став третьою культурою кінця другого - початку третього тисячоліття. Потрібно зауважити, що коли Д. Данін розробляв свою «кентавристику», дизайн як проектна самостійна галузь вже існував. «Кентавристика» виявилася чи не єдиним теоретичним підходом, що спромігся пояснити підстави феномену дизайну як проектної культури. Хоча викладання «кентавристики» роз- 
глядалося її автором як педагогічний експеримент (авторська інтерпретація загальноосвітнього курсу «Концепції сучасного природознавства»), Д. Данін доводив, що ця дисципліна має гідну мету викладання - збудження пізнавальної безкорисливості юнацтва, сприяє розвитку абстрактного мислення, духовному розвитку особистості, що набуває фахових компетентностей (Данин, 1997).

\section{Наукова новизна та практична значимість дослідження}

Наукова новизна представленого дослідження полягає в аналізі стану графічного дизайну в аспекті «кентавристичності» - поєднання непоєднуваного - принципу доповнюваності.

Великий данський фізик Нільс Бор, засновник квантової механіки, висунув принцип доповнюваності або принцип компліментарності, який поклав в основу кентавристики її творець. Цей принцип є дієвим у матеріальному світі органіки і неорганіки. Суть його в тому, щоб не порушити цілісність і тим самим не знищити форму, щоб утворився синтез непоєднуваного (живі організми, культури людського суспільства), потрібні засоби доповнення. Людське середовище й складається з доповнень: велике - мале, біле - чорне, день - ніч, тепле - холодне, збудження - гальмування. Стосовно зорового сприйняття та диференціації електро-магнітного випромінювання мозком людини можна назвати контрастні пари кольорів, що викликають найбільше подразнення (швидке втомлення) ока людини з відповідними відчуттями: червоний - зелений, оранжевий синій, жовтий - фіолетовий. Одночасно, ці кольори є компліментарними, що виявляється за певних умов їх використання та сприйняття. Нільс Бор виявив, що зустріч абсолютно непримиренних один до одного протиріч досягає єдності у природі завдяки принципу доповнення - компліментарності. Учений довів, що принцип доповнюваності проявляється в усіх галузях знань - у біології, психології, лінгвістиці.

«Кентавр» одкровення і науковості, за Д. Даніним, існує реально. Одкровення - це стан релігійного мислення, осяяння (не результат аналізу). Науковість є саме результатом аналізу. Поєднання таких протиріч знайшло відображення в реальній особистості архієпископа Луки - Валентина Феліксовича Войно-Ясинецького, видатного вченого-хірурга, котрий врятував життя багатьом воїнам у Другій світовій війні (Горянин, 2018). Згадаємо сутність протестантської етики, що стала основою формування дизайну як культури і професійної галузі.

Дизайн як абсолютно новий вид діяльності людини, - проектної культури, - можна позначити як «кентавра», поєднання непоєднуваного у формуванні людського середовища життя на сьогоднішньому рівні інформаційно-технічної цивілізації. 
Принцип компліментарності (доповнюваності) потрібно закласти у базу сучасної освіти - формування не тільки гармонійно розвинутої особистості, а й особистості фахівця дизайну, спроможного до проектно-творчого мислення, генерації ідей, що опанував інструменти їх втілення у реальність. В цьому полягає практична значущість нашого дослідження.

Висновки 6 Графічний дизайн як соціально-інформаційна система спілкування є вагомою складовою дизайну середовища. Форми графічного дизайну у поєднанні з формами архітектури утворюють в ідеалі компліментарні умови життєдіяльності людини. Графічні форми інформації викликають певні відчуття і створюють позитивне або негативне (за умов невдалих форм) середовище, налаштовують емоційний стан людей на калокагатію або на деградацію поведінкових моделей. Принципи компліментарності потрібно закласти і в освіту всіх рівнів взагалі, іу фахову освіту галузі дизайну, в усі його напрямки. Дизайн охоплює всі сфери життя людини: за визначеннями сфери діяльності у XX ст. - «від лопати до міста» (1910р.), «від голки до літака» «1960 р.), «від ложки до міста» (1983 р.). «Кентавристично»-науковий підхід до сфери дизайну значно розширює цю сферу. Завдяки росту швидкості науково-технічного прогресу промислове мистецтво (індустріальний дизайн) перетворюється на дизайн середовища, стає елітарною професією, а фахівці дизайну стають елітою інформаційного суспільства. Дизайнери стають своєрідними «квазікентаврами» - фахівцями у кількох напрямках діяльності одночасно: інженерії і мистецтві.

Саме дизайнери формами продукту своєї проектної діяльності формують смаки, бажання, наміри споживачів, надають саме ту інформацію, що потрібна замовникам, іншими словами, впливають івсе частіше керують вибором людини. Так «кентавр» науки і техніки у поєднанні з мистецтвом перетворився на дієвий засіб й інструменти організації середовища буття та на керування вибором споживачів. Графічний дизайн за цієї ситуації доцільно визнати як потужну організуючу складову дизайну середовища як у професійній діяльності, так і в процесі освіти - набуття певних потрібних знань, вмінь, навичок. Проектна культура вимагає фахівців дизайну зі згаданими компетентностями, розвинутими раціонально-логічним та абстрактним художньо-образним типами мислення, що не перетворюються на руйнівну боротьбу, а досягають того рівня компліментарності (доповнення), що сприяє народженню нових ідей, нових проектних форм та їх успішного втілення у реальність. 


\section{Список бібліографічних посилань}

Вершинин, Г.В. (2018). Лекции по истории дизайна. Взято из http://art-design.tyumen.ru/ publication/?m=20181031.

Горянин, А. (2018). Что такое кентавристика? Беседа с Даниилом Даниным о сочетании несочетаемого, 1998. Радио Свобода. Взято из https://www.svoboda.org/a/29154299.html.

Данин, Д.С. (1997). Кентавристика: программа курса для гуманитарных специальностей. Взято из https://kamen-jahr.livejournal.com/462861.html.

Дзогій, Н.С. (2013). Генеза поняття «дизайн». Біоресурси і природокористування, 5(3-4), 163-172.

Мискарян, К. (2007). Дизайн, преобразивший повседневность. Вокруг света, 4, 116-128.

Черкесова, И.Г. (2012). Понятие «Дизайн среды» в контексте дизайн-образования. В Інновації в суднобудуванні та океанотехніці, Матеріали 3-ї Міжнародної науковотехнічної конференції (с. 649-651). Миколаїв: Національний університет кораблебудування ім. адмірала Макарова.

\section{References}

Cherkesova, I.G. (2012). Poniatie "Dizain sredy" v kontekste dizain-obrazovaniia [The concept of «environment design» in the context of design education]. In Innovatsii v sudnobuduvanni ta okeanotekhnitsi [Innovation in Shipbuilding and Ocean Engineering], Proceedings of the 3rd International Scientific and Technical Conference (pp. 649-651). Mykolaiv: Natsionalnyi universytet korablebuduvannia im. admirala Makarova [in Ukrainian].

Danin, D.S. (1997). Kentavristika: programma kursa dlia gumanitarnykh spetcialnostei [Centauristics: course program for liberal arts]. Retrieved from https://kamen-jahr.livejournal.com/462861. html [in Russian].

Dzohii, N.S. (2013). Heneza poniattia "dyzain" [Genesis understood "design"]. Bioresursy i pryrodokorystuvannia, 5(3-4), 163-172 [in Ukrainian].

Gorianin, A. (2018). Chto takoe kentavristika? Beseda s Daniilom Daninym o sochetanii nesochetaemogo, 1998 [What is centauristics? Conversation with Daniil Danin on the combination of the incongruous, 1998]. Radio Svoboda. Retrieved from https://www.svoboda.org/a/29154299. html [in Russian].

Miskarian, K. (2007). Dizain, preobrazivshii povsednevnost [Design that transformed everyday life]. Vokrug sveta, 4, 116-128 [in Russian].

Vershinin, G.V. (2018). Lektcii po istorii dizaina [Lectures on the history of design]. Retrieved from http://art-design.tyumen.ru/publication/?m=20181031 [in Russian]. 